\title{
ANALISIS PENYEBARAN PANAS PADA ALAT PENGERING JAGUNG MENGGUNAKAN CFD (Studi Kasus UPTD Balai Benih Palawija Cirebon)
}

\author{
Engkos Koswara \\ Teknik Mesin Fakultas Teknik Universitas Majalengka \\ Email : ekoswara.ek@gmail.com
}

\begin{abstract}
ABSTRAK
Alat pengering jagung merupakan alternatif proses pasca panen pada produksi jagung. Alat pengering jagung biasanya menggunakan panas sebagai media untuk mengeringkan jagung. Alat ini sangat bermanfaat terutama pada musim hujan, karena biasanya pengeringan jagung dilakukan dengan menjemur jagung tersebut di bawah terik matahari. Pada penggunaannya, alat pengering ini terdapat beberapa masalah. Salah satunya adalah penyebaran panas yang tidak merata terlebih apabila alat pengering ini mempunyai dimensi yang sangat luas. Penyebaran panas ini akan dikaji menggunakan software CFD (Computatitional Fluids Dynamic). Penggunaan CFD dalam kajian penyebaran panas ini diharapkan mampu melihat sebaran panas yang terjadi pada alat yang digunakan. Sehingga dengan penelitian tersebut dapat diketahui sejauh mana efisiensi alat pengering yang digunakan.Pengeringan dengan alat mekanis hanya memakan waktu 18 jam dengan ketebalan tumpukan jagung hingga $45 \mathrm{~cm}$ sedangkan menggunakan matahari dapat memakan waktu sampaii 4 hari.Analisis CFD menghasilkan sebaran panas yang terjadi pada bak pengering. Hasilnya, sebaran panas yang terjadi tidak cukup merata karena penggunaan 1 titik sumber pemanas. Akan tetapi hal tersebut cukup teratasi dengan penggunaan blower sebagai penyebar panas.
\end{abstract}

Kata Kunci : Alat pengering, CFD, penyebaran panas.

\section{PENDAhUluAN}

Jagung selain untuk keperluan pangan, juga digunakan untuk bahan baku industri pakan ternak, maupun ekspor. Teknologi produksi jagung sudah banyak dihasilkan oleh lembaga penelitian dan pengkajian lingkung dan Litbang Pertanian maupun perguruan tinggi, namun belum banyak diterapkan dilapangan.

Penanganan pasca panen merupakan salah satu mata rantai penting dalam usaha tani jagung. Hal ini didasarkan atas kenyataan bahwa petani umumnya memanen jagung pada musim hujan dengan kondisi lingkungan yang lembab dan curah hujan yang masih tinggi. Proses pasca panen jagung terdiri atas serangkaian kegiatan yang dimulai dari pemetikan, pengeringan tongkol, pemipilan tongkol, pengemasan biji dan penyimpanan sebelum dijual ke pedagang pengumpul.

Salah satu rangkaian pasca panen adalah pengeringan, Pengeringan merupakan proses perpindahan panas dari sebuah permukaan benda sehingga kandungan air pada permukaan benda berkurang. Perpindahan panas dapat terjadi karena adanya perbedaan temperatur yang signifikan antara dua permukaan. Perbedaan temperatur ini ditimbulkan oleh adanya aliran udara panas di atas permukaan benda yang akan dikeringkan yang mempunyai temperatur lebih ringan. Aliran udara panas merupakan fluida kerja bagi sistem pengeringan ini. Komponen aliran udara yang mempengaruhi proses pengeringan adalah kecepatan, temperatur, tekanan dan kelembaban.

Alat pengering pada umumnya menggunakan panas sebagai media pengering. Hal demikian dilakukan karena cukup mudahnya mendapatkan sumber panas. Akan tetapi dalam prakteknya, seringkali ditemukan beberapa kendala, salah satunya adalah tidak meratanya panas pada alat pengering yang digunakan. Oleh karean itu, dalam penelitian ini akan

Computer Science | Industrial Engineering | Mechanical Engineering |Civil Engineering 
dilakukan kajian untuk melihat sebaran panas yang terjadi pada alat pengering yang dimiliki oleh UPTD Balai Benih Palawija Cirebon dengan menggunakan software CFD.

\section{METODOLOGI PENELITIAN}

Adapun tahapan - tahapan penelitian adalah sebagai berikut :

1. Studi literature

Pada tahapan ini dilakukan pencairan data berupa jurnal - jurnal terkait dengan penelitian yang akan dilaksanakan

2. Survey lapangan

Pada tahapan ini, akan dilakukan pengamatan langsung di lapangan. Yaitu melihat secara langsung alat pengering yang digunakan di UPTD Balai Benih Palawija Cirebon.

3. Percobaan

Pada tahapan ini, dilakukan pengamatan langsung untuk melihat cara kerja alat pengering di UPTD Balai Benih Palawija Cirebon.

4. Pengambilan data

Pada saat alat pengering digunakan/diuji coba, dilakukan pengambilan data yang dibutuhkan dalam penelitian. Misalkan, temperature, tekanan operasi, dan lain sebagainya.

5. Pengolahan data/simulasi CFD

Setelah pengambilan data pada tahap sebelumnya, kemudian data yang telah diperoleh dilakukan pengolahan data/simulasi CFD pada software untuk melihat sebaran panas yang terjadi.

6. Analisis data

Setelah melihat sebaran panas yang terjadi, kemudian dilakukan analisis data.

7. Kesimpulan dan saran

Penarikan kesimpulan dilakukan setelah analisis data pada tahap sebelumnya dilakukan.

\section{HASIL DAN PEMBAHASAN 3.1 Kadar Air Jagung Pasca Panen}

Panen dan pasca panen tanaman memiliki ciri - ciri kelobot berwarna kuning, biji sudah tua dan berwarna mengkilap pada butiran jagung sudah terbentuk jaringan tertutup berwarna hitam dan bila biji jagung tersebut ditekan dengan kuku tangan maka pada bagian jagung tidak akan membekas, pada kondisi ini perkiraan kandungan air sudah $35 \%$. Setelah dipanen jagung agar dibuka agar kadar air tongkol menurun sehingga terhindar dari serangan jamur, pengeringan tongkol hingga kadar air $17-20$ $\%$ hingga mudah dipipil dan segera dijemur hingga kadar air $15 \%$.

\subsection{Pengeringan dengan Matahari}

Panen komoditas biji - bijian seperti jagung, selalu terjadi pada pertengahan musim penghujan. Kalau awal - awal musim penghujan tahun 2011 ini jatuh pada bulan november, maka panen jagung rendengan (musin penghujan) akan jatuh pada bulan Februari 2012. Pada saat itu, kemungkinan besar sedang puncak musim penghujan. Hingga hampir dipastikan cuaca akan lebih banyak mendung. Sementara kadar air jagung berkisar $25 \%$. Namun ketika hujan turun berkepanjangan, kadar air itu bisa naik antara 30 - $35 \%$. Standar baku kadar air jagung dalam perdangan nasional maupun internasional $14-15 \%$. Dalam kondisi panas matahari normal, pengeringan jagung untuk menurunkan kadar air dari $25 \%$ menjadi $15 \%$ diperlukan waktu antara 2 sampai 3 hari. Dalam cuaca mendung, penurunan kadar air dari $30 \%$ atau $35 \%$ menjadi $14 \%$ sampai $15 \%$ memerlukan waktu 1 minggu sampai 10 hari. Apabila hujan turun sepanjang hari selama beberapa hari, maka produk biji - bijian itu akan membusuk atau tumbuh hingga tidak dapat dikonsumsi manusia lagi.

Karenanya, tidaklah mengherankan apabila setiap panen raya jagung pada pertengahan musim penghujan, selalu diikuti 
pula oleh penurunan harga yang sangat tajam dari kondisi normalnya. Sebab kadar air biji - bijian pada saat panen musim penghujan itu memang lebih tinggi dari panen kemarau. Pada saat panen raya itu penawaran lebih besar dari pada permintaan. Ditambah lagi, biaya penjemuran pada saat itu akan membengkak lebih tinggi disbanding penjemuran pada musim kemarau.

Kondisi yang sudah sangat rutin dan kronis demikian, sebenarnya bisa diatasi dengan sebuah penerapan teknologi. Misalnya dengan menggunakan mesin pengering.

Proses perpindahan kalor pada penjemuran manual, prinsip perpindahan panas pada penjemuran ini adalah proses perpindahan panas konveksi alamiah. Kelebihan dari penjemuran ini adalah mutu yang dihasilkan lebih baik dan kekurangannya adalah membutuhkan tenaga kerja lebih, dan sangat bergantung pada cuaca.

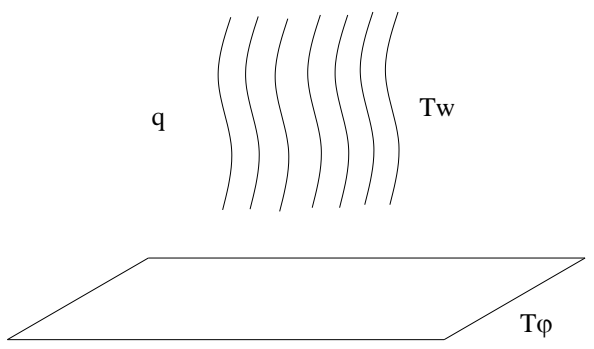

Gambar 3.1 Gambar sistem pengeringan pada proses penjemuran

Gambar di atas menjelaskan proses perpindahan panas pada proses penjemuran, system ini termasuk proses perpindahan panas alamiah karena tidak ada alat bantu dalam proses perpindahan panasnya.

\subsection{Pengeringan dengan Alat Mekanis}

Banyak sekali ditemukan alat - alat pengering dengan berbagai kebutuhan dan spesifikasi. Misal pengering vakum dan pengering yang menggunakan minyak tanah. Pengering vakum, kata vacum berasal dari bahasa latin yaitu vacuus artinya kosong. Jadi vakum artinya menghampakan suatu ruangan atau suatu kemutlakan dibawah nol tekanan. Sistem ruang hampa dikepung oleh atmosfir bumi. Untuk menciptakan ruang hampa diperlukan pompa untuk mengeluarkan udara keluar dari sistem. Kebutuhan ini merupakan arti pekerjaan dasar vakum.

Pengering yang menggunakan minyak tanah, pengering ini menggunakan hasil pembakaran minyak tanah sebagai sumber panas dengan dibantu oleh sebuah blower sebagai pendorong aliran panas yang dihasilkan oleh pembakaran minyak tanah. Dan dengan penggerak blower mengunakan sebuah mesin diesel.

\section{a. Ruang pengering}

Ruang pengering ini mempunyai dimensi dengan lebar $2 \mathrm{~m}$, dan panjang 6,5 m. Sedangkan untuk kedalaman ruang pengeringnya $45 \mathrm{~cm}$. Dan total ketinggian dari bak pengeringnya $90 \mathrm{~cm}$.

\section{b. Kipas / Blower}

Kipas berfungsi untuk mensirkulasi udara kedalam ruang bangunan pengering. Alat ini mempunyai 1 buah kipas, dengan spesifikasi diameter $60 \mathrm{~cm}$ dan panjang sisinya $1 \mathrm{~m}$. Dan putaran dari blower ini 2000 rpm dengan kecepatan udara yang dihasilkan 7,2 m/s. Blower diletakan disamping alat pengering dan didalam blower tersebut terdapat mawar sebagai tempat pembakaran, sehingga blower tersebut berfungsi menghembuskan udara panas hasil pembakaran tungku kedalam ruang pengering.

\section{c. Bahan bakar}

Pengering type dry box ini menggunakan bahan bakar minyak tanah. Minyak tanah tersebut di letakan lebih tinggi dari tempat pembakaran (mawar) hal ini ditujukan supaya minyak tanah bisa mengalir langsung ke pembakaran tanpa 
menggunakan alat bantu, seperti pompa dan lain sebagainya. Panas ini menghasilkan $180{ }^{\circ} \mathrm{C}$ atau $453,15 \mathrm{~K}$.

\section{d. Penggerak}

Untuk menggerakan blower digunakan mesin diesel, dengan type Yanmar TS50. Mesin ini mempunyai daya 4 PK dan putaran 2000 rpm pada daya kerja. Sedangkan untuk daya maksimalnya mesin ini mempunyai daya sebesar 5 PK dan putaran $2400 \mathrm{rpm}$.

\subsection{Analisis CFD}

Analisis CFD dilakukan untuk melihat sebaran panas yang terjadi pada bak pengering. Data yang digunakan dalam analisis CFD berdasarkan hasil pengamatan di lapangan. Data yang dimaksud adalah dimensi bak pengering, temperatur pemanas, dan kecepatan udara yang mengalir ke dalam bak pengering. Hasil analisis CFD berupa gradiasi warna seperti pada gambar di bawah ini.

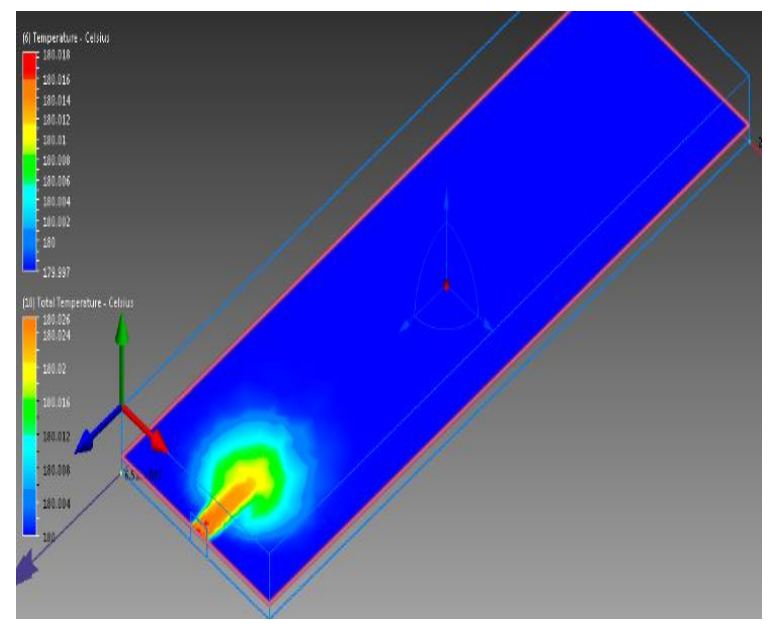

Gambar 3.2 Penyebaran panas pada bak pengering

Dari gambar di atas, terlihat sangat jelas bahwa sebaran panas tidak merata karena menggunakan 1 titik sumber pemanas. Akan tetapi, panas yang dihasilkan mampu memanasi sampai ujung bak pengering. Terlihat pada gradiasi warna, pada ujung bak pengering mencapai temperature $179^{\circ} \mathrm{C}$.
Daerah bak pengering yang paling dekat dengan sumber pemanas bertemperatur 180 ${ }^{\circ} \mathrm{C}$. Hal tersebut menjadi fokus utama pada saat pengoperasian, karena mendapat temperature yang cukup besar, akibatnya jang yang berada pada area tersebut harus sering diaduk supaya jagung mendapatkan panas yang merata. Berbeda halnya dengan jagung yang berada pada ujung bak pengering yang cukup jauh dari sumber pemanas.

Gambar di bawah ini menunjukan arah kecepatan panas yang terjadi pada saat alat pengering dioperasikan.

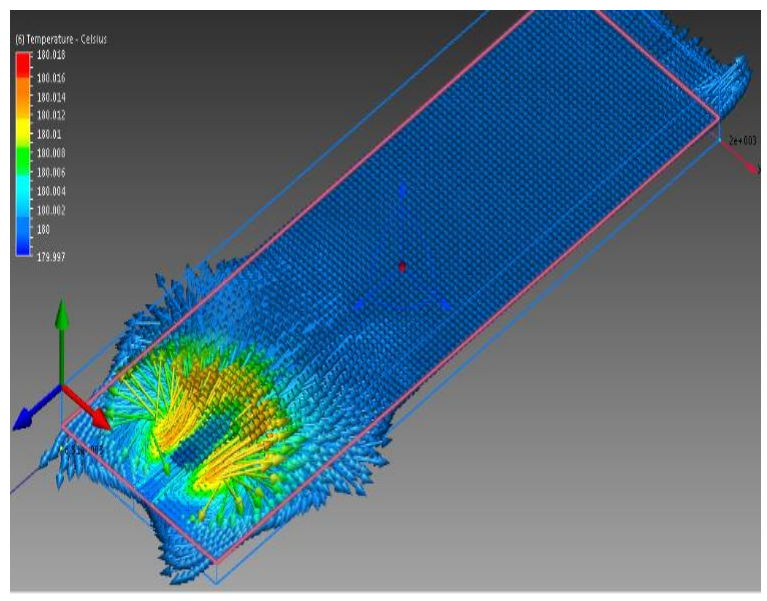

Gambar 3.3 Arah Aliran udara panas

Dari gambar di atas, terlihat jelas kecepatan aliran panas pada area sumber pemanas lebih besar dibandingkan pada ujung bak pengering. Hal ini mengakibatkan pada ujung bak pengering lebih lama proses pemanasannya dibandingkan dengan area dekat sumber pamanas.

\section{KESIMPULAN \\ 4.1 Kesimpulan}

Dari penelitian yang telah dilakukan, dapat disimpulkan beberapa hal. Diantaranya

1. Proses pengeringan jagung menggunkanan sumber pemanas berupa api yang dihasilkan dari pembakaran minyak tanah. Dari pembakaran tersebut, 
2. panas yang dihasilkan kemudian disebarkan ke bak pengering dengan menggunakan blower untuk menyebarkan panas yang dihasilkan

3. Dilihat dari analisis CFD yang dilakukan, penyeberan panas panas yang terjadi tidak merata, karena sumber pemanas hanya berada pada 1 titik. Akan tetapi cukup teratasi dengan penggunaan blower. Terbukti panas pada ujung bak pengering mencapai $179^{\circ} \mathrm{C}$.

\subsection{Saran}

Dari hasil penelitian yang telah dilakukan, terdapat beberapa saran. Diantaranya :

1. Untuk mendapatkan panas yang merata pada tiap titik, diperlukan sumber pemanas di titik lain.

V. Diperlukannya pengontrolan temperatur, supaya temperatur yang sampai ke jagung tidak berlebihan

\section{DAFTAR PUSTAKA}

J. P. HOLMAN, Perpindahan Kalor, Edisi Keenam

IPB (Bogor Agriculture University), Analisis Distribusi Suhu, Aliran Udara, RH dan Kadar Air dalam InStore Dryer (ISD) Untuk Biji Jagung.

I. U. Firmansyah, M. Aqil, dan Yamin Sinuseng, Penanganan Pasca Panen 